zaserger

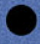

0

thend

$\sum_{4}+y^{2}+v^{4}$

米

s.ie.

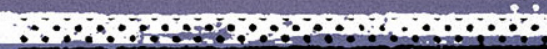

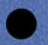

ofses

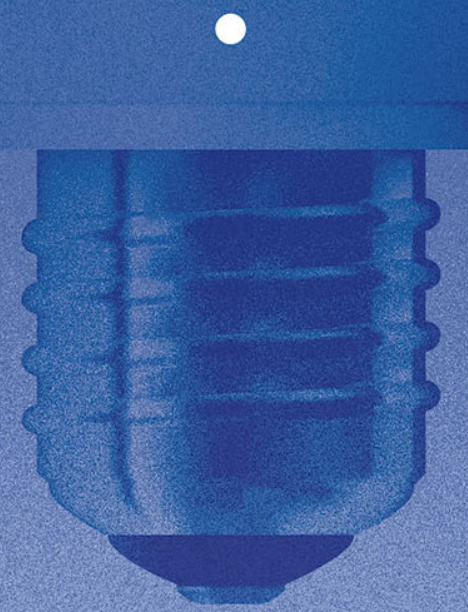

$8 y^{2}$

इ1

$\$$
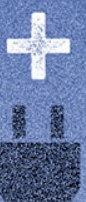


\title{
State-owned enterprises and foreign infrastructure investment in Brazil after the 2008 international financial crisis
}

\author{
Empresas Estatais Empresas estatais e \\ investimento estrangeiro em infraestrutura \\ no Brasil após a crise financeira \\ internacional de 2008
}

\author{
Fernando Amorim Teixeira* \\ Gustavo Teixeira Ferreira da Silva**
}

\begin{abstract}
The article aims to analyze the participation of BNDES, Eletrobras and foreign investors in infrastructure megaprojects in Brazil after the 2008 international financial crisis. The research adopts a heterodox, Keynesian and institutionalist perspective, to conduct an empirical analysis, using the World Bank's database on private participation in infrastructure. The results show that the ten largest projects carried out in the Brazilian electricity sector after 2008 had the participation of foreign capital, of which eight had the participation of BNDES and six with the participation of Eletrobras.
\end{abstract}

Keywords: State-owned Enterprises; Foreign Investors; Infrastructure Investment.

\begin{abstract}
Resumo
Empresas Estatais Empresas estatais e investimento estrangeiro em infraestrutura no Brasil após a crise financeira internacional de 2008. O artigo tem como objetivo analisar a participação de $B N D E S$, Eletrobras e de investidores estrangeiros em megaprojetos de infraestrutura no Brasil após a crise financeira internacional de 2008. A pesquisa adota uma perspectiva heterodoxa, de inspiração keynesiana e institucionalista, para realizar uma análise empírica de recorte setorial, utilizando a base de dados do Banco Mundial sobre participação privada em infraestrutura. Os resultados demonstram que os dez maiores projetos realizados no setor elétrico brasileiro após 2008 tiveram a participação de capital estrangeiro, sendo que oito contaram com a participação do BNDES e seis com a participação da Eletrobras.
\end{abstract}

Palavras-chave: Capital Estrangeiro; Investimento em Infraestrutura; Setor Elétrico Brasileiro.

\footnotetext{
* PhD candidate in the Post-graduation Economic Program at the Universidade Federal Fluminense (PPGE-UFF). https://orcid.org/0000-0003-3718-7940.E-mail: fernando_tx@yahoo.com.br

** Advisor of Federação Nacional dos Urbanitarios (FNU). http://dx.doi.org/0000-0003-1664-8197.

E-mail: gteixeiraeconomia@gmail.com
} 


\section{INTRODUCTION}

The relationship between the state and market presents particularities regarding the development of arrangements for investments in infrastructure. In this sense, state-owned companies are important instruments of interaction between the public and private spheres, since they have a relevant economic role in several countries. Due to their corporate and public nature, they are related market structures and financial stability, as well as the public budget and implementation of economic policy measures. Therefore, they are able to fulfil different functions to stimulate private investment, whether in structuring financing, investing in partnership with other groups or even individually.

According to the Organisation for Economic Co-operation and Development (OECD, 2018), in the recent period, the participation of state-owned enterprises has increased even in international trade and investment. In 2015, all OECD member and guest countries (except China) had 2,467 state-owned enterprises, with an estimated market value of about $\$ 2.4$ trillion and over 9 million employees. China can be considered as a separated universe due to the size and number of state-owned companies: in 2015 , it had 51,000 state-owned companies, totalling $\$ 20.0$ trillion in market value and 20 million employees (OECD, 2017).

The need to manage infrastructure investments as public policies, which means, within the logic of planning, requires attention to costs, but also the results for economic and social development. The state must, therefore, be able to pursue projects that are fundamental to the country's development and create efficient instruments for attracting and managing (or even investing directly), as well as setting priorities. At the same time, dealing with interests of this magnitude implies understanding the diverse conjunctures and portfolio strategies of major investors. It follows that, from time to time, domestic and international investors are more (or less) likely to invest in certain assets, depending on their risks and returns

However, the role, which for many years was restricted to the state, including through state-owned enterprises, became gradually to be "transferred" to private actors in a variety of modalities. Thus, privatization, public concessions with different financing mechanisms, and various types of public-private partnerships (PPP) were stimulated to leverage large infrastructure projects. Moreover, the limitation posed by the need for prior expertise and the ability to mobilize large amounts of capital, limited a portion of these resources to foreign investors (via large sector players), especially in developingcountries

In the case of Brazil, there was a peculiar movement in the post-international crisis: a considerable increase in foreign investment in the country and private participation in infrastructure. According to the perspective adopted in this article, this situation may be related to the role that state-owned companies played in arrangements. Therefore, it is considered that investigating the logic of such investments may shed light on 
the current debate about what role the state, and especially state-owned enterprises, should play within a development strategy.

The article is separate into three sections, besides the introduction and the conclusion. Initially, a brief theoretical review of Keynesian and institutionalist inspiration focusing on the relationship between state and market in contemporary capitalism. The following describes the scope and research methodology. The last section presents the results

\section{STATE, MARKET, INSTITUTIONALITY AND VARIETIES OF CAPITALISM}

In order to understand the constitutive - and therefore not antagonistic - nature between the state and the market and the importance of both in the process of developing countries finds, some authors can give a robust theoretical basis. Polanyi's (2001) critique of the belief that both national societies and the global economy find its equilibrium through the so-called self-regulation of markets is unique in this regard. The state would play a major role in the supply of money and credit, for example, and the conflict between the expansive tendencies of self-regulating markets and defensive political measures (of resistance and containment) would start from a dialectical perspective, and its conditioning are historically constructed.

The contradictory development of economies would result from the simultaneous existence of both (state and market) and the action provoked by economic liberalism, confronted with the principle of social protection and productive organization. The centrality of organization, regulation, and control exercised by states would thus be inherent in systemic logic, not the opposite. In short, there is no realism in resign State as a mere broker of the so-called "market failures", since it is the entity that establishes the institutional framework in which economic processes develops.

Nevertheless, after a period where state coordination in the economic process was paramount (starting in the post-World War II until the mid-1970s), there was a movement in which various currents of liberal revisionism converged on a "definitive" pattern of the object of study and methodology of Macroeconomics centred on the role of the market (WOODFORD, 2009). Based on models of intertemporal general equilibrium, backed on microeconomics fundamentals, these theoretical strands departs by the basic assumption that only the freely acting market would allocate resources as best as possible towards a long-term general equilibrium. In this perspective, monetary policy would be the most effective instrument of economic policy (mainly to control inflation), and it is not for the state to resort to fiscal policy or other spending instruments - to try to leverage the economy - as they would only generate allocative distortions.

By the early 1990s, developed countries had already broadened into this perspective, but it was not until the second half of the decade that this movement 
reached most of the developing countries. In this period, financial globalization has made in fact, the capital market as the essence of modern capitalism (TORRES, 2013). Market deregulation and widespread capital mobility meant that adjustments came almost instantaneously, giving a new face to short and long-term investments. Even so, the insertion of the various economies and the deconstruction of the states - as we knew before- occurred in a non-homogeneous way, generating vulnerabilities and different opportunities regarding potential interventions in the economy.

Financial openness raised interest rates to another dimension for external equilibrium, and rate differentials became a centrepiece for understanding flows. Such a feature would derive from the value reserve function of the different currencies, a function that has gained even more importance in a context of exacerbation of the financial sphere. Due to the so-called opportunity cost, it becomes almost natural to feedback on the currencies that are appreciating, generating a reallocation of portfolios and strengthening the hierarchy between them (DE CONTI, PRATES AND PLIHON, 2013, P.30).

From the perspective of financial globalization, leave the state "out" of what was for decades under its purview (which includes undertaking large infrastructure projects) would require a greater presence of private capital in "low-return" investments and would require maturing long-term in specific arrangements. Thus, by using resources more "efficiently", it would be possible to carry out a great number of projects, as well as freeing public resources for other priority expenditures. If the application of such prescriptions would have the potential to create considerable disruption in developed countries, transposing them - uncritically - into developing countries (with weaker states and less developed markets), would naturallygenerategreater obstacles, which includes:

1. The presumption that there is a hydraulic functioning of the economy and that market structures are given in time and space;

2. The belief that short, medium and long term fluctuations would not generate "differentiated" unpredictability from country to country and;

3. Relegating a secondary role to the state, little attention would be paid to the perception that materializing large-scale investments would depend on designing them as a public policy perspective (conforming and shaping the institutionality of each country).

Faced with these challenges, the theoretical perspective adopted in this paper has a more realistic approach. As institutions are (necessarily) the result of social processes, the different market mechanisms are also creations of this nature and it has influencesin economic processes. However, they are not the only ones and, therefore, has to be faced taking the complexity of the modus operandi of the economy in each jurisdiction. 
The Keynesian approach that individual agent's decisions start from subjective beliefs about the future would thus be the most appropriate. Given the impossibility of holding all the information and given that the world is complex and dynamic, uncertainty would be an intrinsic feature of a monetary economy of production. Because of this, the institutions develop itself to reduce different uncertainties, depending on the characteristics of the country and conjunctures.

The logic of advancing resources in a monetary production economy derives from the borrower's future income expectations and the risk-return expectations - for those who acquire the created assets. According to Studart (1993, p. 102), the role of the financial system in the post-Keynesian view is more complex and essential than that of a simple broker between investors and savers. In this sense, there is a need for a stable institutional environment to allow stable financial growth, and the existence of longterm financing mechanisms, which not always happen through market forces.

In the case of long-term investments, given the inherent risks of maturity mismatch, as the timing of borrowing and return, it generates greater risks. Thus, the existence of appropriate markets and/or institutions can provide the foundation for financially solid growth. In other words, funding is central to making longer-term investments and doing so through private mechanisms, has limitations in each jurisdiction, which may require alternative ways to avoid mismatches.

Moreover, it is part of the essence of modern capitalism that agents may incur risks linked to the very nature of investments, as developed by Minsky (1986) and known as the Financial Instability Hypothesis. In general, there would be an inherent tendency in modern monetary economies, depending on the duration of a country's economic stability, for agents to allow themselves to take more risks, and a reversal of this stability could undermine the ability of the most indebted firms to renegotiate their liabilities.

Regarding theinstitutionalist approach, it is associated with the concept of perpetuity and stability of institutions, where rules, norms and procedures are defined, in a way to structure interactions between agents (HODGSON, 2006). In this sense, they can sometimes embarrass, sometimes stimulate actions, since they guide expectations and uncertainties. From this perspective Evans (2003) criticizes what he called "institutional monoculture", capable of transcending national circumstances, politically and geographically. according to the author, "[a] institutional monoculture's not only has few possibilities to solve local governance problems; It also has the potential to make financial lending less effective" (EVANS, 2003, p. 50)

Under a state conception of Weberian "rationality," such institutionality develops into explicit regulations and interventions within their legal domain. Thus, the State acts in a continuous undertaking of public functions instituted by laws and distributed in differentiated competences. In addition, behaves historically in evolution, that is, changes in parallel with the development of the modern financial economy - even without direct causality. 
Therefore, in the "financialization" process, it is not possible to understand it only from the perspective of the market, but taking into account the state's responses (AKYÜZ, 1993). Given that, the development trajectories adopted by countries are diverse and shaped by a symbiosis of the relationship between the state and the market and by systemic structures and conjunctures. Therefore, it would not be possible to form a single model of capitalism, but of varieties of capitalism (HALL \& SOSKICE, 2001).

\section{INFRASTRUCTURE INVESTMENT IN BRAZIL AFTER THE 2008 INTERNATIONAL FINANCIAL CRISIS: SCOPE AND METHODOLOGY OF THE RESEARCH}

Infrastructure investments have direct and indirect influence on economic and social development, with relevant impacts on the economic level activity, productivity and, therefore, on economic growth (CALDERÓN \& SERVÉN, 2003; ESTACHE \& FAY, 2007). Not surprisingly, the topic of infrastructure, as well as its financing, has taken a centre stage in recent G-20 meetings. According to the Inter-American Development Bank (IADB):

Policymaking processes, like policies, are very complex. Multiple actors with diverse powers, time horizons, and incentives interact in various arenas. There are diverse rules of engagement which can have an impact on the way the game is played. For these reasons, it is not possible to fully understand these processes by focusing on a few institutional characteristics [...]. (IADB, 2006. p. 30)

Such enterprises are natural monopolies with high scale gains, capital-intensive activities in the implementation phase and have a high sunk cost. Thus, they are part of a list of possible interventions of command and control by the public entity, as the definition of the equity concentration degree, debt, regulation, among others. In many cases, it also requires direct state action (giving guarantees), as in projects with the participation of state-owned enterprises.

At the same time, contractual specificities are key to addressing and tracking issues such as cost, regulation and any eventual re-negotiation needs. Thus, privatization of infrastructure assets, Public-Private Partnerships (PPP) or even concessions of various types - including Special-Purpose Entities (SPEs), can develop in dialogue with the specificities listed above. SPE is a business modality that seeks to isolate risks, as well as to prevent managers from having discretion about the use of cash flow, allowing the regulator to have accurate financial information. In the case of financing, Project Finance is the most common mechanism for structuring a project in which the financier and the investor (sponsor) are legally independent. That is, assumes the cash flow in addition to project assets -, are a primary source of funding guarantee (SIFFERT et al, 2009). 
From the 2000s, the logic of adapting large projects to the new financial reality has become more latent and initiatives have multiplied worldwide, according to Word Bank Private Participation in Infrastructure (PPI). However, unlike what might be assumed, given the increased degree of uncertainty, it was in the years following the 2008 crisis that these projects increased most. It is also from this period that there was a substantial increase in foreign investment inflows to Brazil.

According to World Bank data, between 2008 and 2017, PPI in Brazil reached US\$ 257 billion (635 projects), of which US\$ 135.8 billion (426 projects) in the electricity sector. The post-crisis PPI volume (up to 2014) even exceeded the amount of PPI during the privatization process that took place in the country in the second half of the 1990s.

Graph 1. Private Participation in Infrastructure and Foreign Direct Investment inflow, Brazil, 1995-2017, current US\$ million

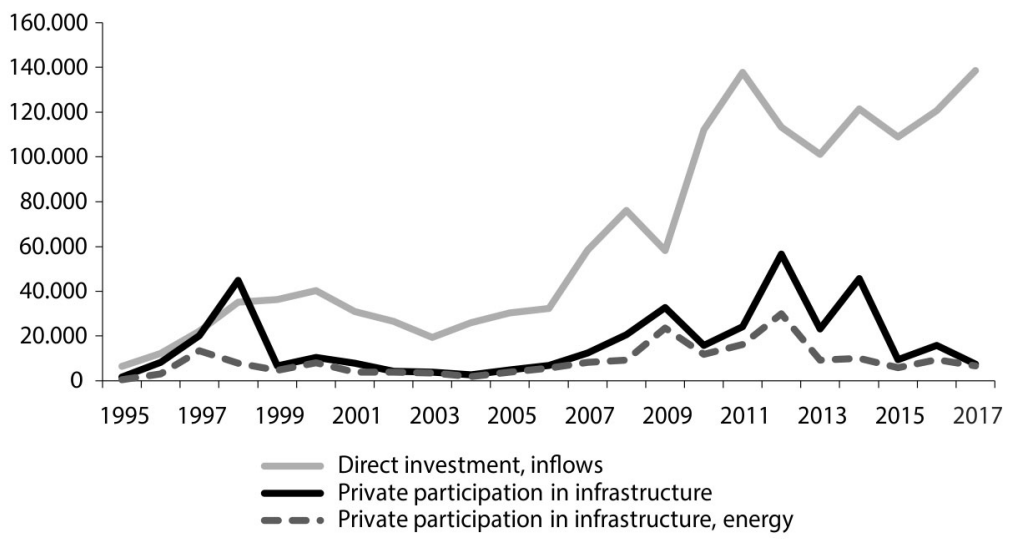

Source: World Bank and IPEADATA - self-elaboration.

As can be seen in Graph, although PPI registered a significant decrease from 2014, the FDI inflow remains at a high level. One possible explanation is that, in the recent period (under the context of the political and economic crisis) privatization and concessions program adopted by Michel Temer's administration in 2016, much of the capital inflow has been reported for investments in form of merger and acquisition. It should be remembered that this type of transaction (brownfield) is less related to economic dynamics than greenfield projects, which have the greatest impact on the level of investment (constitution of assets), employment and income generation, productivity, and therefore for economic growth.

Public investment also made an important contribution to the economic performance of the country until the 2015 crisis. According to Orair et al (2018), in the period 2007-2010, public sector investments and federal state-owned companies grew at an average annual rate of $17.0 \%$ and $23.0 \%$, respectively. Nevertheless, the level of 
public investment in infrastructure, which averaged 2.2\% of GDP per year over the last decade, insufficient to compensate capital depreciation (PEREIRA \& PUGA, 2016).

In the case of the electricity sector, since the mid-2000s, the Economic and Social National Development Bank (BNDES) and Eletrobras, in addition withseveral institutional and regulatory changes, have contributed to the strong expansion of private investment in infrastructure. According to Werner (2017), the improvement of the regulatory framework in 2004 contributed to minimize risks and generate greater capacity to originate and plan projects. Law 10,847 (which created the Energy Research Company) and Law 11,079 (which established general rules for bidding and contracting PPPs) were essential to leverage investments in the sector. The requirement to set up SPE allowed financing through Project Finance's financial engineering. Most recently, Law 12,431 created the so-called Infrastructure Equity Investment Funds and Law 12,766 amended the previous legislation, including variable remuneration mechanisms, innovations concerning the partnership guarantee fund. It is also worth mentioning Brazilian institutionality in the sector, formed by the National Council of Energy Policy, the Ministry of Mines and Energy, the National Electric Energy Agency, the Electric Energy Trading Chamber, the Electric Sector Monitoring Committee and National Electric System Operator.

According to Graph 2, the BNDES disbursements for the electricity sector increased from 2006 to 2014. In the case of Eletrobras, it is possible to observe the significant growth of investment in the period from 2008 to 2013 and a very sharp fall from 2015 . Eletrobras's investment policy in partnership with other groups led the state-owned company to register participation in more than 170 SPEs, a modality that accounted for about half of the group's investment in the period.

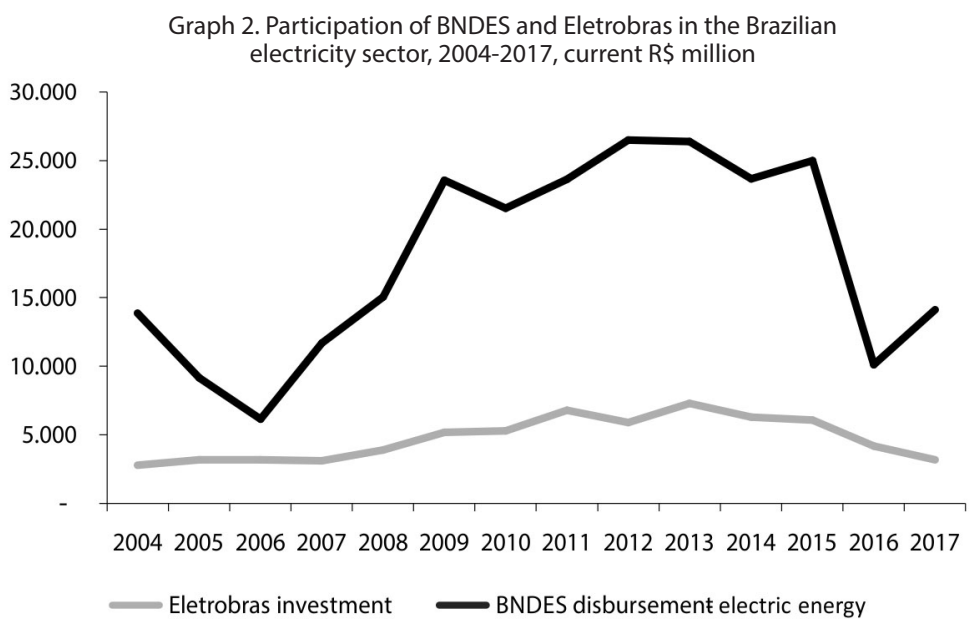

Source: BNDES and Ministério do Planejamento do Brasil - self-elaboration. 
The delimitation of the object of research is to understand the logic behind these investments, especially in the context of exacerbation of the degree of uncertainty arising from the international financial crisis. The proposed methodology is an empirical analysis, by sectoral cut, of the ten largest projects carried out in the Brazilian electricity sector. The source of the data is the World Bank's database on private participation in infrastructure. From this data, it is possible to identify, for example, the fixed value in capital assets, the agents involved (investors and financiers), the nationality of the agents, among other information. In addition, we investigate the financial statements of each firm in order to detail the information on the corporate structures of the projects and their respective participants.

\section{STATE-OWNED COMPANIES AND FOREIGN PARTICIPATION IN MEGA PROJECTS CARRIED OUT IN THE BRAZILIAN ELECTRICITY SECTOR AFTER THE 2008 CRISIS}

Considering the survey data, the ten largest private equity holdings (Greenfield modality) in the Brazilian electricity sector totalized US\$38.7 billion, representing over $30 \%$ of the total PPI registered in the country. Table 1 (below) provides a summary of the survey results. Most of the projects took place between 2009 and 2012, derived by the constitution of SPEs and using the Project Finance financing modality.

Table 1. Ten largest private Investments in the Brazilian electric sector, Greenfield Modality, 2008-2017

\begin{tabular}{|c|c|c|c|c|c|c|}
\hline Ranking & Company-investment & Year & $\begin{array}{l}\text { Value } \\
\text { (US\$ } \\
\text { millon) }\end{array}$ & $\begin{array}{c}\text { BNDES } \\
\text { financing } \\
\text { (US\$ millon) }\end{array}$ & $\begin{array}{l}\text { Electrobrás } \\
\text { participation }\end{array}$ & $\begin{array}{c}\text { Foreign } \\
\text { investment } \\
\text { participation }\end{array}$ \\
\hline 10 & $\begin{array}{l}\text { Belo Monte } \\
\text { (generation) }\end{array}$ & 2012 & 14.800 & 13.415 & $49,90 \%$ & Spain $(10 \%)$ \\
\hline $2^{\circ}$ & $\begin{array}{l}\text { Santo Antônio } \\
\text { (generation) }\end{array}$ & 2009 & 6.800 & 3.100 & $43,00 \%$ & $\begin{array}{r}\text { Spain (10\%) } \\
\text { Portugal (10\%) }\end{array}$ \\
\hline $3^{\circ}$ & Jirau (generation) & 2009 & 5.300 & 4.800 & $40,00 \%$ & $\begin{array}{r}\text { France }(40 \%) \\
\text { Japan }(20 \%)\end{array}$ \\
\hline $4^{\circ}$ & Brookfield (generation) & 2010 & 2.241 & n.d. & - & Canada (100\%) \\
\hline $5^{\circ}$ & TelesPieres (generation) & 2012 & 1.896 & 1.510 & $49,20 \%$ & Spain $(51 \%)$ \\
\hline $6^{\circ}$ & IEMA (transmision) & 2012 & 1.793 & Sim & $49,00 \%$ & Colombia (51\%) \\
\hline 70 & $\begin{array}{l}\text { Belo Monte } \\
\text { (transmision) }\end{array}$ & 2017 & 1.762 & 1.140 & $49,00 \%$ & China $(51 \%)$ \\
\hline $8^{\circ}$ & Parnaiba (generation) & 2011 & 1.634 & 700 & - & Germany (30\%) \\
\hline $9^{\circ}$ & $\begin{array}{l}\text { Porto Pecen } \\
\text { (generation) }\end{array}$ & 2009 & 1.400 & Sim & - & $\begin{array}{l}\text { Germany }(22 \%) \\
\text { Portugal }(50 \%)\end{array}$ \\
\hline $10^{\circ}$ & $\begin{array}{l}\text { Tucurui - Oriximana } \\
\text { (transmision) }\end{array}$ & 2010 & 1.109 & - & - & Espanha (100\%) \\
\hline
\end{tabular}

Source: World Bank e CompaniesAccounting Statements- self-elaboration. 
According to this Table, all projects had foreign participation,tottalingeight nationalities. In this regard, at least three aspects are important to highlight:

1. The foreign companies participating in these projects are major players in the world energy sector and many of them have an important participation in Brazil, such as Neonergia - Iberdrola (Spain), Brookfield (Canada), Engie (France) and State Grid (China).

2. Some of them are State-Owned (State Grid) or have the state ownership, directly from the state or by another state enterprise. These are the cases of the French group Engie, in which the French state is the largest shareholder; and the Portuguese group Electricity of Portugal (EDP), where the largest shareholder is the Chinese state-owned company China Three Gorges (CTG).

3. It is possible to identify the strong and widespread presence of Investment Funds in the ownership composition of these corporations - a striking feature of the current stage of the financial globalization process. Neoenergia, for example, has a stake in Previ (Banco do Brasil Investment Fund), while Iberdrola, the company's controller has, as the largest shareholders, the BlackRock Investment Fund and Qatar Sovereign Fund (Qatar Investment Authority). Those funds are also part of the shareholding structure of the Portuguese group EDP.

Given those information, it would be possible to affirm, for example, that the 7th ranking venture, Belo Monte Transmission, despite being listed in the World Bank database as private participation in infrastructure, is, in fact, a purely state venture, since all participating companies are state-owned: two national (BNDES and Eletrobras) and one foreign (State Grid). In the case of the 9th ranking venture, Porto Pecen, it can be considered that the foreign participation of the Portuguese group EDP represents a Chinese state-owned company (CTG), there is an American Investment Fund and also the Qatar Sovereign Fund.

Regarding national state participation, BNDES participated in eight projects, of which the amount financed exceeded US\$ 25.0 billion. Eletrobras registered participation in six projects (the largest ones), through its subsidiaries: Chesf, Eletronorte, Eletrosul and Furnas. In addition, it was possible to identify other national state holdings: the Minas Gerais State Electric Power Company (CEMIG) in the Belo Monte hydroelectric power plant, and the Banco da Amazônia (BASA) in the TucuruiOrixamana transmission line.

Finally, as an illustration of the complexity and diversity of agents participating in these projects, it is worth mentioning some aspects presented in the case study of the Teles Pires hydroelectric dam, elaborated by Vazquez, Hallack and Queiroz (2016). In summary, the Teles Pires Energia Efficient Consortium, consisting of Neoenergia/ Iberdrola, Eletrobras/Eletrosul, Eletrobras/Furnas and Odebrecht Energia, won the auction held by Regulatory Agency (ANEEL) in 2010. The SPE Companhia Hidrelétrica 
Teles Pires S/A, for the construction, assembly, operation and maintenance activities of the plant's generation facilities. Another consortium, formed by the companies Odebrecht Energia, Voith, Alston, PCE and Intertechne, had beenstructured under EPC (engineering, procurement and construction) to carry out the project and civil works, as well as supply and assemble the electromechanical equipment of the enterprise

In the financial plan, resources of $\mathrm{R} \$ 3.6$ billion were leveraged in three financing levels: (i) long-term financing; (ii) equity financing and (iii) short-term financing through bridge loans. Long-term funds were obtained from the BNDES Finem and BNDES Finame financing lines, with a 20-year amortization term. Financing of $R \$ 1.2$ billion was stipulated and a transfer of $\mathrm{R} \$ 2.4$ billion (besides $\mathrm{R} \$ 450$ million for the short term). Twenty-year simple private debentures amounting $\mathrm{R} \$ 650$ million were also issued, the only buyer of which was the Caixa Econômica Federal State Investment Fund (Vazquez; Hallack and Queiroz, 2016,P.30).

\section{CONCLUSION}

The objective of the paper was to analyze the participation of state-owned and foreign companies in infrastructure investments in Brazil after de recent International Crisis. To this end, a Keynesian and institutionalist perspective on financing and investment in infrastructure sector was adopted. Given the specificities and the long-time horizon of this type of investment, it was argued about the need for a - de facto - constitutive relationship between the state and market for the proper development of arrangements that enable the mobilization of large volumes of capital. It has been assumed that the development trajectories adopted by the countries are diverse and shaped by a symbiosis of both and by the systemic structures and conjunctures.
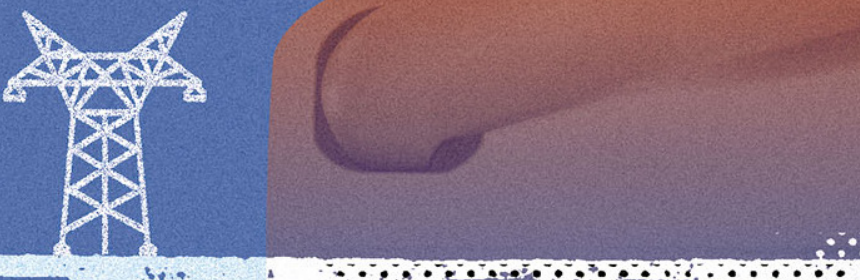
Given the elements concerning modern Capitalism, financialized and shorttermed, the need to develop certain guarantees for private equity participation, such as the role of state-owned companies to reduce the inherent uncertainties of these kind of investments, was highlighted. As presented, the existence and active performance of state-owned companies in different development processes is common in many countries. In OECD countries and China, there are thousands of state-owned companies, investing inside the country and abroad.

The object of analysis was the post-crisis international environment, in which, despite the international financial instability, there was a significant increase in both foreign capital inflows and private participation in infrastructure in Brazil (mainly in the electricity sector). The World Bank's database on private participation in infrastructure was fundamental to analyze the ten largest projects carried out in the Brazilian electricity sector.

The results of the sectorial cut showed that all projects had the participation of large foreign players. Most projects have been incorporated through modern market mechanisms that seek to reduce business risks (SPEs and Project Finance engineering modality). However, it could be said that the dilution of risks derived not only from these mechanisms but also from the strong state participation in the projects. In addition to Eletrobras and BNDES, other national and foreign state holdings were identified. In this sense, as part of the conclusion we could realize that national stateowned companies and foreign investors (including state-owned companies) made it possible - even at an unfavourableconjuncture. Finally, it should be mentioned that the results of these investments were not evaluated in the present research, and should, therefore, be considered in the broader context of the development strategy adopted by the Brazilian State in the period in question - including the different externalities generated in a social and environmental point of view.

\section{References}

AKYÜZ, Y. Financial liberalization: the key issues. In: AKYÜZ; HELD (orgs.). Finance and the real economy: issues and case studies in developing countries. United Nations University; Economic Commission for Latin America and the Carribean, 1993.

CALDERÓN, C. e SERVÉN, L. The Effects of Infrastructure Development on Growth and Income Distribution. Washington DC: Grupo Banco Mundial, 2004.

DE CONTI, B., PRATES, D. \& PLIHON, D. O Sistema Monetário Internacional e seu caráter Hierarquizado. In: Cintra, M. \& Martins (orgs.). A. As transformações no sistema monetário internacional. Brasília: Ipea, p. 23-84, 2013.

EVANS, P. Além da "monocultura institucional": instituições, capacidades e desenvolvimento deliberativo. In: Sociologias, n. 9, 2003, p. 20-63.

HALL, P.; SOSKICE, D (org.), 2001. Varieties of Capitalism: The Institutional Foundations of Comparative Advantage. New York: Oxford University Press, 2001.

HODGSON, G. What Are Institutions? Journal of Economic Issues, v. XL, n. 1, March 2006. 
INSTITUTO DE PESQUISA ECONÔMICA APLICADA. Condicionantes Institucionais à Execução de Projetos de Infraestrutura: Financiamento de Longo Prazo. IPEA, TD 2266, Rio de Janeiro, 2016 INTER-AMERICAN DEVELOPMENT BANK. The Politics of Policies: Economic and Social Progress in Latin America: 2006 Report. Washington DC: Inter-American Development Bank., 2006.

MINSKY, H. Stabilizing an Unstable Economy. Yale University Press, 1986.

OCDE. Diretrizes da OCDE sobre Governança Corporativa de Empresas Estatais, Edição 2015. Paris: OECD Publishing. Disponível em: https://bit.ly/2URDHRa. Acesso em: 10 Out. 2019.

OCDE. The Size and Sectoral Distribution of SOEs in OECD and Partner Countries. Paris: OECD Publishing, 2017. Disponível em: https://bit.ly/37omjGd . Acesso em: 10 Out. 2019.

ORAIR, R.O.; SIQUEIRA, F. F. Investimento público no Brasil e suas relações com ciclo econômico e regime fiscal. Economia e Sociedade, Campinas, v. 27, n. 3 (64), p. 939-969, setembro-dezembro 2018.

PEREIRA, A.; PUGA, F. Infraestrutura no Brasil: ajustando o foco. TD 112, BNDES, 2016, 26p.

POLANYI, K. The great transformation. The Political and Economic Origins of Our Time. Boston: Beacon Press, 2001.

SIFFERT, N.; ALONSO, L.; CHAGAS, E.; SZUSTER, F.; SUSSEKIND, C. O papel do BNDES na expansão do Setor Elétrico nacional e o mecanismo do Project Finance. Rio de Janeiro: BNDES, 2009. Disponível em: https://bit.ly/2OWmMcn. Acesso em: 10 Out. 2019.

STUDART, R. O sistema financeiro e o financiamento do crescimento: uma alternativa póskynesiana à visão convencional. Revista de Economia Política, v.13, n. 1(49), janeiro-março, 1993.

TORRES, E. A Crise do Sistema Financeiro Globalizado Contemporâneo. 2013 (mimeo).

VAZQUEZ, M.; HALLACK, M. e QUEIROZ, R. Condicionantes Institucionais à Execução de Projetos de Infraestrutura: Financiamento de Longo Prazo. IPEA, TD 2266, Rio de Janeiro, 2016. Disponível em: https://bit.ly/2SOAsYb. Acesso em: 10 Out. 2019.

WERNER, D. A atuação do BNDES na política do Setor Elétrico brasileiro: 2002-2014. In: Vainer, C e Braga, F. (org.). BNDES: grupos econômicos, setor público e sociedade civil. Rio de Janeiro: Garamond, 2017.

WOODFORD, M. Convergence in Macroeconomics: Elements of the New Synthesis. American Economic Journal: Macroeconomics, American Economic Association, v. 1, n. 1, p. 267-279.

Bases de Dados:

BNDES. Disponível em: https://bit.ly/2SNRiWT.

WORLD BANK. Disponível em: https://ppi.worldbank.org/.

IPEADATA. Disponível em: http://www.ipeadata.gov.br.

BRASIL. Ministério do Planejamento e Orçamento. Disponível em: https://bit.ly/3bFR2SI. 